Povarenkov, 2002 - Povarenkov YU. P. Psihologicheskoe soderzhanie professionalnogo stanovleniya cheloveka / YU. P. Povarenkov. - M. : Izd-vo URAO, 2002. - $160 \mathrm{~s}$.

Subbotina, 2011 - Subbotina L. YU. Formirovanie professionalnoy gotovnosti studentov k samostoyatelnoy deyatelnosti. / L. YU. Subbotina // YAroslavskiy pedagogicheskiy vestnik. - 2011. - № 4. - T. II. - S. 295298.

Shipilova, 2007 - Shipilova E. V. Formirovanie psihologicheskoy gotovnosti studentov-psihologov k professionalnoy deyatelnosti : avtoref. dis. na soisk. nauch. stepeni kand. psihol. nauk : spets. 19.00.07 «Pedagogicheskaya psihologiya». - Moskva, 2007. - 20 s.

УДК 316.334.22:130.123(092)

Ольга Стрілець, кандидат педагогічних наук, доцент кафедри мистецьких дисциплін і методик навчання ДВНЗ «Переяслав-Хмельницький державний педагогічний університет імені Григорія Сковороди».

\section{DOI 10.31470/2308-5126-2019-45-2-130-135}

\author{
Olga Strilets,
}

Ph.D. in Pedagogy, Associate Professor of the Department of Art Disciplines and Teaching Methods of the SHEI «PereiaslavKhmelnytskyi Hryhorii Skovoroda State Pedagogical University».

E-mail: ostrilets5@gmail.com

ORCID 0000-0003-1797-3784

\title{
ПОГЛЯДИ ВАСИЛЯ СУХОМЛИНСЬКОГО НА ПРАЦЮ ЯК ДУХОВНУ ПОТРЕБУ ПІДРОСТАЮЧОГО ПОКОЛІННЯ
}

У статті розглянуто питання актуальності формування у підростаючого покоління духовних цінностей. Розкрито важливість педагогічних порад великого педагога Василя Сухомлинського щуодо праці, як засобу виховання: «високоморальної, гуманістично спрямованої, фізично досконалої, естетично розвиненої особистості відданої своєму народові, своїй Батьківщині, яка не є байдужою до горя й біди інших людей, яка співчуває іншому та в разі потреби надає йому допомогу». Здійснений ретроспективний аналіз праць Василя Сухомлинського дозволив зробити висновок, щуо педагог надавав великого значення саме духовному вихованню дітей і стверджував про те: «що ідеал - ие духовна сериевина особистості. Прагнення до ідеалу - ие перший поштовх, стимул до самовиховання, без якого духовне життя особистості не $\epsilon$ повноцінним». 3 огляду на цее, вченому-педагогові важливим бачиться розвинути у підлітків, юнаків $і$ дівчат здатність бути вихованими, навчити їх виховувати самих себе. Обтрунтовано, щяо ідеї В. О. Сухомлинського щуодо духовного виховання підростаючого покоління засобами праці були, є $і$ будуть актуальними завжди.

Ключові слова: духовні цінності, високоморальність, ідеал, самовиховання, прачя, творча особистість, емоційно-естетичне виховання, творча прачяя.

The article deals with the relevance of the formation of spiritual values in the younger generation. The importance of the pedagogical councils of the great teacher Vasily Sukhomlinsky about labor as a means of education is revealed: if necessary, assists him. A retrospective analysis of the work of Vasily Sukhomlinsky led to the conclusion that the teacher attached great importance to the spiritual education of children and argued that «the ideal is the spiritual core of the personality. The pursuit of the ideal is the first impetus, the incentive to selfeducation, without which the spiritual life of the individual is not complete». As the term, the word «spirituality» is used in such sciences as philosophy, ethics on the definition of different concepts in one way or another tangible to the inner world of man. Spirituality is an ideal, to which the person sought and aspires to his own development, orientation to higher, absolute values, as well as the manifestation of the maturity of the psyche of the personality of the activity of the signaling system. The pedagogical problems of V.O. Sukhomlinsky are related to the problem of the formation of the spiritual nature of one of the third places. About the goal of the book of books and statuses, and the very same: "The Holy Spirit of the People of Our Hour», "The Spiritual Life of the Collective Collective», "The Spiritual Culture», «Creativity Is the Impetus of Spiritual Life» vihiovannya.

V. O. Sukhomlynsky convinced in his article «Work in the spiritual life of a teenager» What does an idea mean: labor is the basis of all-round development? In practical work with children and adolescents, this means that from the work there are strong strands of intellectual, moral, aesthetic, emotional, physical development until the formation of the ideological, civil basis of the individual. Education and labor can not be simplified, as practical consolidation, verification of the practice of knowledge acquired in the class. This problem is deep and sophisticated: mental development - labor, reason - labor. 
Spirituality as high is opposed to the low, imperfect, vulgar, immoral, sinful. Considering this, it is important for a teaching scientist to develop in adolescents, boys and girls the ability to be educated, to teach them to educate themselves. It is substantiated that the ideas of Sukhomlinsky on the spiritual education of the younger generation were the means of labor that are and will always be relevant.

Keywords: spiritual values, visokomoralnist, ideal, self-education, work, creative personality, emotional and aesthetic education, creative work.

Постановка проблеми. Концептуальні положення щодо розвитку глибоко духовної та творчої особистості на ідеях національного відродження України знайшли відображення у Конституції України, Законах України «Про освіту» (1991), Державній національній програмі «Освіта» («Україна XXI століття» (1994), Національній державній комплексній програмі естетичного виховання (2006) та ін. Ці та інші документи декларують право кожної особистості на художньо-естетичний розвиток, визначають пріоритети національної освіти щодо формування особистості на культурних, мистецьких, естетичних, духовних, загальнолюдських і національних цінностях.

Видатний український педагог Василь Олександрович Сухомлинський стверджував, що «працю називають могутнім вихователем, але ії виховна сила ще не розкривається тоді, коли руки підлітка чимось зайняті. Праця, відірвана від ідейного, інтелектуального, морального, естетичного, емоційного, фізичного виховання, від творчості, від інтересів, від багатогранних відносин між вихованцями, стає повинністю, яку їм хочеться швидше «відбути», щоб залишилося більше часу на більш цікаві справи.

Великим злом у багатьох школах є те, що праця не стає духовною потребою. Це збіднює духовне життя людини в роки становлення його поглядів, переконань. Лінь часто розквітає як тяжка біда і порок не тому, що людина нічого не робить, а тому, що робота не надихає, чи не одухотворяє його, не залишає позитивного сліду в емоційній пам'яті» [Сухомлинський, 1980: с. 612].

За тлумачним словником української мови слово першооснова духовність пов'язана 3 внутрішнім психічним життям людини, іiі моральним світом. Як термін слово «духовність» використовується у таких науках, як філософія, етика на означення різних понять так чи інакше дотичних внутрішньому світові людини. Духовність - це ідеал, до якого прагнула й прагне людина у іï власному розвитку, орієнтація на вищі, абсолютні цінності, а також це $є$ прояв зрілості психіки особистості діяльністю сигнальної системи.

Духовність як високе протиставляється низькому, недосконалому, вульгарному, аморальному, гріховному. Незважаючи на абстрактність поняття, в узусі дуже часто слово духовність використовується як конкретна якість чи мало не реально існуюча субстанція, про що свідчить слововжиток на зразок «людина великої духовності», «дефіцит духовності в суспільстві» тощо [Словник української мови, 1971: с. 445].

Філософи (О. Бердяєв, В. Соловйов, О. Лосєв та ін.) і педагоги (Г. Бриль, I. Бужина, О. Барабаш, Н. Кузнєцова та ін.) «духовність» ототожнюють 3 духовною культурою, розглядають іï як поведінковий аспект. Інші вчені (М. Каган, I. Силуянова, В. Стрєлков, В. Федотов та ін.) вбачають у духовності внутрішню якість особистості, один із чинників свідомості людини.

У педагогічній спадщині В. Сухомлинського проблема формування духовності посідає одне з провідних місць. Про це засвідчують його книги і статті, а саме: 
«Духовний світ людини нашого часу», «Духовне життя шкільного колективу», «Духовна культура», «Творчість - могутній стимул духовного життя», «Обмін духовними цінностями», «Праця і моральне виховання» і таке інше. Під духовно вихованою людиною В. Сухомлинський розумів високоморальну, гуманістично спрямовану, фізично досконалу, естетично розвинену особистість віддану своєму народові, своїй Батьківщині, яка не є байдужою до горя й біди інших людей, яка співчуває іншому та в разі потреби надає йому допомогу» [Сухомлинський, 1980: c. 707].

Аналіз останніх досліджень $\boldsymbol{i}$ публікацій. Проблема творення духовного світу особистості дитини постає в спадщині В. Сухомлинського як категорія педагогіки, психології, філософії. Це відображено в публікаціях про нього і в дослідженнях його науково-педагогічної діяльності, зокрема в дослідженнях таких науковців: Є. Андреєва, М. Антонець, І. Бех, Л. Бондар, А. Борисовський, Л. Петрук, Т. Паніманська, О. Савченко, О. Сухомлинська, М. Ярмаченко. Значним внеском у вивчення життя та практичної діяльності, складових педагогічної системи В. Сухомлинського стали праці М. Антонця, І. Беха, А. Богуш, М. Богуславського, В. Бутенка, М. Вашуленка, Г. Волкова, С. Заволоки, І. Зязюна, В. Кузя, Н. Ничкало, М. Мухіна, В. Паламарчук, А. Розенберга, В. Смаля, М. Сметанського, В. Хайруліної та ін.

Окремим аспектам педагогічної системи В. Сухомлинського присвячені кандидатські дисертації М. Библюка, А. Бика, Л. Бондар, Т. Будняк, М. Левківського, А. Луцюка, Л. Мілкова, І. Остапйовського, Т. Остапйовської, О. Петренко, Л. Петрук, Л. Сіднєва, О. Соколовської, З. Шевців, К. Юр'євої. У дослідженнях цих науковців визначено внесок В. Сухомлинського у розвиток різних напрямів вітчизняної педагогічної науки. Зокрема, широко розроблене В. Сухомлинським питання естетичного виховання молодших школярів, що стало предметом наукового дослідження Т. Будняк. До розгляду цієї проблеми зверталися також у кандидатських дисертаціях Л. Петрук «Виховання школярів засобами народної педагогіки у творчій спадщині В. О. Сухомлинського».

Mema cmammi - проаналізувати погляди В. Сухомлинського на проблему формування духовності у молодого покоління засобами праці. Адже у своїй діяльності педагог відводив праці центральне місце у вихованні дітей. Акцентувати увагу на його думки про значення праці в розвитку і становленні особистості, виховання любові до праці, ставлення до праці, формування внутрішньої потреби в праці, радість праці, формування трудової культури як однієї з важливих складових духовності людини.

Виклад основного матеріалу. Науково-педагогічні праці великого українського педагога В. Сухомлинського сповнені духовними ідеями, хвилюючими роздумами, глибокими поглядами, цінними рекомендаціями щодо духовного виховання підростаючого покоління. Василь Олександрович був переконаний у тому, що гуманне громадянське суспільство можуть побудувати лише люди гуманні, толерантні, здатні до усвідомлення себе як вищої цінності, які мають бажання удосконалити життя громадян власної держави.

В. Сухомлинський вважав, що ідеал - це духовна серцевина особистості. Прагнення до ідеалу - це перший поштовх, стимул до самовиховання, без якого духовне життя особистості не є повноцінним. 3 огляду на це, вченому-педагогові важливим бачиться розвинути у підлітків, юнаків і дівчат здатність бути вихованими, навчити їх виховувати самих себе. «Здатність бути вихованим - це 
чутливість душі, чутливість серця вихованця до найтоншого відтінку слова вихователя, до його погляду, до руху, до посмішки, до задумливості й мовчазності...» [Сухомлинський, 1976: с. 496].

У своєму творі «Праця у духовному житті підлітка» В. Сухомлинський переконував «Що означає ідея: праця - основа всебічного розвитку? У практичній роботі з дітьми та підлітками це означає, що від праці йдуть міцні нитки до інтелектуального, морального, естетичного, емоційного, фізичного розвитку до становлення ідейної, цивільної основи особистості. Навчання і труд не можна представляти спрощено, як практичне закріплення, перевірку на практиці знань, одержаних на уроці. Ця проблема глибока і витончена: розумовий розвиток - праця, розум - праця. Уміле вирішення цієї проблеми у вихованні підлітків має особливе значення. Знайти таку працю, яка б розвивала розумові сили і здібності, вводила б людину у світ творчості - одна 3 головних завдань розумового i трудового виховання. Праця стає основою гармонійного розвитку особистості також тому, що в трудовій діяльності людина стверджує себе як громадянин, переживає почуття громадянської гідності. Він відчуває, що здатен добувати не тільки хліб насущний, але й матеріалізувати свій розум, свою творчість. Громадянське повинно бути не у дзвінкому вислові, а у душі -це одне з найважливіших правил трудового виховання. Відчуття громадянської значимості праці - це разом 3 радістю пізнання, світосприйманням надзвичайно сильний емоційний стимул, що одухотворяє нелегку працю, а праця тільки тоді виховує, коли вона нелегка. Сдність праці і емоційноестетичного виховання досягається тільки тоді, коли людина, пізнаючи світ працею, створює красу, стверджуючи цим в собі відчуття краси праці, творчості, пізнання». [Сухомлинський, 1976: с. 613].

У роботах «Павлиська середня школа», «Духовний світ школяра», «Як виховати справжню людину», «Народження громадянина», «Праця і моральне виховання» праця викладена В. Сухомлинським як духовно-гуманістична система виховання, що грунтується на таких методологічних положеннях: а) духовність $€$ однією 3 найвищих цінностей, моральним виміром людської життєдіяльності, джерелом ii етнічної самостійності; б) на формування духовного світу особистості впливають не тільки суспільні відносини, а й специфічне середовище, в якому відбувається становлення особистості; в) процес становлення духовної культури грунтується на принципах комплексного й системного підходів у вихованні, включаючи в себе взаємодію об'єктивних і суб'єктивних чинників.

Духовність визначається В. Сухомлинським як головний принцип життєдіяльності людини, який уможливлює ії особисте і суспільне щастя. Людина, «яка не визначила свого місця в суспільстві, стає особисто нещасливою, а кожен нещасливий - це лихо суспільства» [Сухомлинський, 1976: с. 203].

У своїй роботі «Звичка працювати» педагог писав: «В роки отроцтва звичка працювати об'єднується 3 осмисленням ролі праці, як важливої духовної потреби. Підліток замислюється над своїм місцем у житті, свідомо прагне виразити свою індивідуальність. У цей період важливо не тільки те, скільки і як працює людина, але й те, що вона думає про працю». Далі Василь Олександрович стверджував, що «Тільки праця у всій своій багатогранності направлена на пізнання, на світосприйняття, на самовираження, самоствердження особистості в творчості, тільки насичення вільного часу працею, що збагачує духовне життя, може дати людині щастя. Адже без праці людина буде приречена на муки Тантала: в ситуації матеріального багатства він залишиться бідним, і як казав Тарас Шевченко, 
«душеубогим». Отже, В. Сухомлинський переконує, що: «Чим більше працює підліток за власним бажанням, тим глибше входить в його духовне життя люба робота, тим більше цінить він вільний час і вміє користуватися ним як джерелом добра і радості».

Педагог вважав за необхідне не тільки в період отроцтва, але й з дитинства широко залучати учнів до різноманітних видів творчої праці. Природно, що виховання працею, на думку вченого, розпочинається за шкільною партою, оскільки навчання $є$ найважчою працею для школяра. «Досягнення в творчій праці - пише В. Сухомлинський у своєму дослідженні «Формування уявлення про вищу мету життя в процесі праці», позначається на всіх сторонах духовного життя дитини. Вони сповнюють ії життя радістю, допомагають переборювати труднощі, вселяють упевненість у своїх силах. Чим більших успіхів добилась людина в отроцтві і юності, тим конкретніше уявляє вона своє життя в майбутньому».

Василь Сухомлинський стверджував, що саме любов до праці - це прояв духовного життя. «Буденну, одноманітну, звичайну роботу молодь виконує 3 великим захопленням, якщо в основу ії крім значної суспільної мети, покладено ще й цікавий творчий задум. Людина не повинна бути тільки виконавцем праці, а й творцем праці. Виховна мета праці повинна полягати не тільки в тому, щоб виконати певний обсяг роботи, добути певний матеріальний результат, а й у тому, щоб внести в звичні трудові процеси щось нове, підняти працю до ступеня творчості. Духовний розвиток людини досягає високого рівня тоді, коли вона до моменту вступу в пору юності вже матиме певний досвід творчої праці. Дуже важливо, щоб в отроцтві у неї зародилась творча думка, захопила свідомість до праці» [Сухомлинський, 1962: c. 51].

Високу мету виховної роботи В. Сухомлинський вбачав у тому, щоб кожній молодій людині дати моральну, розумову, практичну і психологічну підготовку до творчої праці. Педагог писав: «В естетичному ставленні до процесу і результатів трудової діяльності знаходить свій вияв повнота духовного життя. Людина все більше й більше бачить у праці не тільки матеріально-практичну, а й творчу, духовну цілеспрямованість. Завдяки цьому праця розглядається не тільки як необхідність, але насамперед як вільна діяльність. Чим яскравіше виявлена ця сторона праці, тим більше віддана людина улюбленій справі, тим помітніше місце займає звичайна, здавалося б, непримітна праця в ії духовному житті, тим більше прагне вона проникнути в деталі, «секрети» трудової майстерності, тим більше зусиль докладає в подоланні труднощів» [Сухомлинський, 1962: с. 131].

Висновки. Отже, аналіз процесу виховання в учнівської молоді духовності засобами праці в науково-практичній діяльності В. Сухомлинського дозволяє зробити висновок, що, за словами педагога: «Багатство духовного життя людини усвідомлює і переживає лише в тому разі, коли підвищується культура іiі праці. Критерієм культури праці є поєднання розумових і фізичних зусиль, творчість. Це одна $з$ найважливіших умов всебічного розвитку людини». Формування духовних цінностей у дитини розпочинається саме в родині і тому надзвичайно цінним подальшим дослідженням є проблема моральних та духовних цінностей сім'i.

\section{ЛІТЕРАТУРА}

Бех, 2004 - Бех І. Д. Педагогіка сердечності В. О. Сухомлинського / І. Д. Бех // Науковий вісник Миколаївського державного університету. Педагогічні науки: зб. наукових праць. Випуск № 8. Миколаїв : МОУ, 2004. - С.18.

Словник української мови, 1971 - Словник української мови: в 11 томах. - Том 2, 1971. - С. 445. 
Сухомлинський, 1976 - Сухомлинський В. О. Проблеми виховання всебічно розвиненої особистості / В. О Сухомлинський // Вибр. тв.: у 5 т. - К.: Рад. шк., 1976. - Т.1. - С. 55-206.

Сухомлинський, 1962 - Сухомлинський В. О. Праця і моральне виховання / В. О. Сухомлинський. - К.: Рад. шк., 1962. - С. 51, 131.

Сухомлинський, 1967 - Сухомлинський В. О. Вибрані твори : в 5 т. / В. О. Сухомлинський. - К. : Рад. шк., 1976. - T. 4. - 1976. - 640 с.

Сухомлинський, 1977 - Сухомлинський В. О. Вибрані твори в п’яти томах / В. О. Сухомлинський. - Т. 3. -К. : Рад. Школа, 1977. - 707 с.

Сухомлинський. 1976 - Сухомлинський В. О. Проблеми виховання всебічно розвиненої особистості / В. О. Сухомлинський // Вибр. твори : в 5 т. - К. : Рад. школа, 1976. - Т. 1. - С. 5-402.

\section{REFERENCES}

Bekh, 2004 - Bekh I. D. Pedahohika serdechnosti V. O. Sukhomlynskoho / I. D. Bekh // Naukovyi visnyk Mykolaivskoho derzhavnoho universytetu. Pedahohichni nauky: zb. naukovykh prats. Vypusk № 8. Mykolaiv : MOU, 2004. - S.18.

Slovnyk ukrainskoi movy, 1971 - Slovnyk ukrainskoi movy: v 11 tomakh. - Tom 2, 1971. - S. 445.

Sukhomlynskyi, 1976 - Sukhomlynskyi V.O. Problemy vykhovannia vsebichno rozvynenoi osobystosti / V.O. Sukhomlynskyi // Vybr. tv.: u 5 t. - K.: Rad. shk., 1976. - T.1. - S. 55-206.

Sukhomlynskyi, 1962 - Sukhomlynskyi V.O. Pratsia i moralne vykhovannia / V.O. Sukhomlynskyi. - K.: Rad. shk., 1962. - S. 51, 131.

Sukhomlynskyi, 1967 - Sukhomlynskyi V. O. Vybrani tvory : v 5 t. / V. O. Sukhomlynskyi. - K. : Rad. shk., 1976. T. 4. $-1976 .-640 \mathrm{~s}$.

Sukhomlynskyi, 1977 - Sukhomlynskyi V. O. Vybrani tvory v piaty tomakh / V. O. Sukhomlynskyi. - T. 3. - K. : Rad. Shkola, 1977. - 707 s.

Sukhomlynskyi. 1976 - Sukhomlynskyi V. O. Problemy vykhovannia vsebichno rozvynenoi osobystosti / V.O. Sukhomlynskyi // Vybr. tvory : v 5 t. - K. : Rad. shkola, 1976. - T. 1. - S. 5-402.

Світлана Танана,

кандидат педагогічних наук, дочент кафедри професійної освіти

ДВНЗ «Переяслав-Хмельницький

державний педагогічний університет імені Григорія Сковороди».
Svitlana Tanana,

Ph.D. in Pedagogy, Associate Professor of the Department of Professional Education,

SHEI «Pereiaslav-Khmelnytskyi

Hryhorii Skovoroda

State Pedagogical University».

E-mail: tananasvetlana@gmail.com

ORCID 0000-00026088-0738

\section{ФОРМУВАННЯ КОМУНІКАТИВНОЇ КОМПЕТЕНТНОСТІ МАЙБУТНІХ ТОВАРОЗНАВЦІВ У ПРОЦЕСІ ЗАСВОСННЯ ДИСЦИПЛІН ФАХОВОГО СПРЯМУВАННЯ}

У статті досліджено теоретичні питання та особливості формування комунікативної компетентності майбутніх товарознавців у процесі засвоєння дисииплін фахового спрямування у закладах вищої освіти. Доведено, що формування комунікативної компетентності майбутніх товарознавців передбачає оволодіння навичками усвідомленого спілкування у межах науково-дослідної, організаційноуправлінської, виробничо-технологічної та професійної галузей, а врахування окреслених особливостей сприятиме ефективному формуванню комунікативної компетентності майбутнього товарознавия. Визначено: для ефективного виконання професійної діяльності товарознавці повинні мати не лише інтегровані фахові знання та вміти їх використовувати, а й досконало володіти знаннями гуманітарного циклу, оскільки людина водночас є як суб'єктом, так $і$ об'єктом нерозривно пов'язаного зі спілкуванням процесу управління. Акиентовано на специфічних особливостях формування комунікативної компетентності товарознавців, виявлено взаємозв'язок гуманітарних $і$ фахових дисииплін. Професійні якості, як мобільність, комунікабельність та діловитість майбутніх товарознавців, надзвичайно пов'язані $з$ його професійною успішністю, яка виявляється в багатьох показниках, а саме: у професійній компетентності, постійному фаховому та особистісному зростанні. 